\title{
Antonio de Fuenmayor's Life of Pius V: A Pope in Early Modern Spanish Historiography
}

\begin{abstract}
Antonio de Fuenmayor's Vida y Hechos de Pío V (1595) is one of the earliest hagiographic texts written about Pius $V$, the most famous of Counter-Reformation popes and the victor of the Battle of Lepanto (1571). But, because Fuenmayor wrote in Spanish rather than Italian, his text has never received much attention. This article presents it in its context for the first time and argues that it highlights an important problem in developing genre of early modern Spanish historiography: how to incorporate the pope in the national histories promoted by Philip II, III, and IV? Contemporary Spaniards praised the Vida y Hechos de Pío V highly, a fact which may have had as much to do with its highly political role as a critical rebuke of Clement VIII and, later, of Urban VIII as it did with the text's literary qualities. The fact that Fuenmayor's depiction of Pius $V$ is just as interesting and carefully constructed as the better-known Italian examples reminds us to be careful how we prioritize such examples of Counter-Reformation hagiography. Moreover, its existence underlines how Italians, who staffed most of the papacy's offices at this time, hardly held a monopoly on projecting or defining the papacy's image. Other Catholics, in this case the Spanish Monarchy and its agents, in order to further their own political interests, put forward rival visions that were at odds with those emanating from Rome.
\end{abstract}

KEYWORDS: Pius V, Philip II of Spain, Hagiography, Historiography, Early Modern Papacy, Early Modern Spain

The sixteenth and seventeenth centuries were a golden age for historiographers and for those who wrote papal biography. Europe's princes had followed Italy's civic republics in developing historical knowledge as a political tool. At the same time, 'Lives of popes', both collective and individual, had emerged as an important genre within Tridentine Catholic literature and served a variety of functions: they documented the history of Catholic Christianity, confirmed anticlerical prejudices in the papacy's critics, offered exemplary models of holiness, and made political points about the pope's role in contemporary society. This article concerns a particular vita of Pius V which was also part of what Nicholas Popper has termed the late sixteenth century's 'political turn of history' - the moment when, in the midst of religious polemics and conflicts, princes began to incorporate historiographical methods into their realpolitik. ${ }^{1}$ Antonio de Fuenmayor's Vida y Hechos de Pío V. Pontifice Romano, published in Madrid in 1595, is obscure - certainly compared to Girolamo Catena's Vita del gloriosissimo papa Pio Quinto, written nine years earlier (and later re-worked in Latin by Giovanni Gabuzio in 1605). ${ }^{2}$ Moreover, that obscurity has not been accidental: while Leopold von Ranke

\footnotetext{
${ }^{1}$ Nicholas Popper, Walter Raleigh's History of the World and the Historical Culture of the Late Renaissance (Chicago: University of Chicago Press, 2012), 6.

${ }^{2}$ Antonio de Fuenmayor, Vida y Hechos de Pio V. Pontifice Romano, dividida en seis libros; con algunos notables sucessos de la Christianidad del tiempo de su Pontificado (Madrid: Luis Sanchez, 1595). Fuenmayor's original text exists in a modern, though not critical, edition, ed. Lorenzo (Llorenç) Riber, Vida y Hechos de Pío V de Antonio de Fuenmayor (Madrid: Real Academia Española, 1953), which I have used for references in this article.
} 
quickly incorporated Catena's vita into the materials of secondary scholarship, he and later scholars jettisoned Fuenmayor's as biased and parti pris. ${ }^{3}$ Yet, I hope to show in this article not only that Fuenmayor's Vida y Hechos de Pío V is the equal of Catena's for historical and historiographical interest, but also that it highlights an evolving problem in the developing schools of historical writing at Catholic courts: how to include the pope in their 'national' histories and how to describe his authority viz-a-viz the temporal sovereign. Fuenmayor's Vida offers a subtly different vision of Pius from Catena's and underlines how Italians, who staffed most of the papacy's offices at this time, did not have a monopoly on projecting or defining the papacy's image. Other Catholics, in this case the Spanish Monarchy and its agents, in order to further their own political interests, put forward rival visions that were at odds with those emanating from Rome.

Antonio de Fuenmayor's Vida y Hechos de Pío V is the third known biography of Pius V, the Dominican who, as Fra Michele Ghislieri, had risen from humble origins in Bosco in Piedmonte to the summit of the ecclesiastical hierarchy: friar at fourteen, priest at twenty-four, bishop, cardinal and grand inquisitor by fifty-eight, and finally supreme pontiff when he succeeded Pius IV on $7^{\text {th }}$ January 1566 at the age of sixty-one. 4 Contemporaries found Ghislieri's story compelling, not least because of his deep personal piety and extreme personal austerity, a lifestyle which by the time of his pontificate had rendered him frail, emaciated and constantly sick. The whiff of holiness which he gave off chimed with the new spirit of Tridentine Catholicism, attracting admirers even before his election; after it, it helped Pius to shape the nascent image of the pope as saint within contemporary Catholic discourse. ${ }^{5}$ Fuenmayor's Vida y Hechos

Girolamo Catena, Vita del gloriosissimo papa Pio Quinto dedicate al santissimo Signor Nostro Sisto V. Con una raccolta di lettere di Pio V a diversi Principi \& le risposte con altri particolari, e i nomi delle galere et di capitani così christiani come turchi che si trovarono alla battaglia navale. Dall'istesso autore riveduta \& ampliata (Rome, 1586); Giovanni Gabuzio, De vita et rebus gestis Pii V. Pont. Max. libri sex auctore Io. Antonio Gabutio Novariensi presbytero Congragationis Clericorum Regolarium S. Pauli (Rome: Aloysio Zannetti, 1605).

${ }^{3}$ Leopold von Ranke, History of the Popes, their Church and State, trans. E. Fowler (3 vols., New York: Colonial Press, 1901), Vol. 1, 244n.

"Scholarship on Pius' life is considerable, though there have been few modern biographies. Recent studies include Nicole Lemaître, Saint Pie V (Paris: Fayard, 1994); Simone Feci, Pio V, in Enciclopedia dei papi, (3 vols., Rome: Trecciani, 2000), Vol. 3, 16080, Virgino Giacomo Bono, San Pio V Ghislieri: Quinto centenario della nascità di S. Pio V (Garbagnate Milanese: Anthelios, 2004); Maurilio Guasco and Angelo Torre (eds.), Pio V nella società e nella politica del suo tempo (Bologna: Il Mulino, 2005); Fulvio Cervini and Carla Enrica Spantigati (eds.), Il tempo di Pio V, Pio V nel tempo: atti del Convegno internazionale di studi, Bosco Marengo, Alessandria, 11-13 Marzo 2004 (Alessandria: dell'Orso, 2006).

${ }^{5}$ Florence Buttay, 'La Mort du Pape entre Renaissance e Contre-Réform: Les Transformations de l'image du sovrain pontife et ses implications (fin XVe - fin XVIe siècle)', Revue Historique, 625 (2003), 67-94; Maria Antonietta Visceglia, Morte ed elezione del papa: norme, riti e conflitti. L'età moderna (Rome: Viella, 2013), 97-146; Agostino Paravicini Bagliani, The Pope's Body, trans. David S. Peterson (Chicago: University of Chicago Press, 2000). 
de Pío $V, 147$ folios long in the original edition, recounts Pius' remarkable life across six books. The first observes Pius up to the point of his election as pope; the second, by contrast, paints a portrait of Pius as supreme pontiff: the virtues manifest in him, his attempts to channel his personal austerity into a programme for all Romans, and his heroic efforts to reform the Church. The third enlarges the frame of reference by considering Pius' diplomacy, including his initial policy towards the Protestants in Germany, his reaction to rebellion in Corsica, and the nunciature he sent to France to coordinate efforts against heresy there. The fourth and fifth books are more focused: on Spain and the events surrounding the Revolt of the Alpujarras there from 1568-71, and on Gian Francesco Commendone's second legation to Germany in 1571. The sixth presents Pius' great victory of Lepanto in 1571, an event which Pius himself encouraged everyone to see as his crowning achievement. Fuenmayor narrates the great difficulties that confronted the Christian forces: the mercurial nature of the pope's Venetian allies, the famous story of Pius' miraculous vision of the victory from the window of his apartment in the Vatican, and the ostentatious triumph Pius allowed Marcantonio Colonna to conduct through the streets of Rome. The Book ends with an account of Pius' peaceful death as he recited from the Lord's Prayer ('deliver us from all evil and receive us at the hour of our death...'), followed by brief reflections on his manifest holiness and his momentous impact on the Catholic Church.

Pamela Jones, Miguel Gotor and Roberto Rusconi have all written at length about Pius' long road to canonization and the major texts produced in support of it in Italian. ${ }^{6}$ However, neither they nor scholars of Spain have said much as yet about this unique piece of hagiography about Pius in Spanish. The reasons for this are perhaps two-fold. First, Fuenmayor now appears as just a relatively minor Iberian cleric, writing in local vernacular, who was too far removed from the papal court to trouble papal historians. Equally, Fuenmayor's subject - an Italian pope - has perhaps lowered the priority he might otherwise have been accorded by the scholars who are currently advancing our knowledge of Spanish historiography at the courts of Philip II and Philip III. ${ }^{7}$ Of Antionio de Fuenmayor himself we know little except that he was born in c.1571 into the minor nobility of north-eastern Castile. A small number of texts describe his immediate family,

${ }^{6}$ Miguel Gotor, 'Le vite di San Pio V dal 1572 al 1712 tra censura, agiografia e storia', in Guasco and Torre, Pio V nella società e nella politica, 207-49; Roberto Rusconi, Santo Padre: La santità del papa da San Pietro a Giovanni Paolo II (Rome: Viella, 2011), 246-70; Pamela Jones, 'The Pope as Saint: Pius V in the eyes of Sixtus V and Clement XI', in James Corkery and Thomas Worcester (eds.), The Papacy since 1500: from Italian Prince to Universal Pastor (Cambridge: Cambridge University Press, 2010), 47-68.

${ }^{7}$ Alfredo Alvar Ezquerra, 'Sobre la historiografía castellana en tiempos de Felipe II', Torre de los lujanes, 32 (1996), 89-106 and 'La historia y los historiadores y el Rey en la España del Humanismo', in Alfredo Alvar Ezquerra (ed.), Imágenes históricas de Felipe II (Madrid, Centro de Estudios Cervantinos, 2000), 217-252; Fernando Álvarez Bouza, Communication, Knowledge, and Memory in Early Modern Spain, trans. Sonia Lopez and Michael Agnew (Philadelphia: University of Pennsylvania Press, 2004); Richard Kagan, Clio and the Crown: The Politics of History in Medieval and Early Modern Spain (Baltimore: The Johns Hopkins University Press, 2009); Alfredo Alvar Ezquerra and Fabien Montcher, 'Miguel de Cervantes: A Fictional Historian Writing Real Fiction during the Political Turn of History (c. 1570-1615)', Cervantes. Bulletin of the Cervantes Society of America, 34 (2014), 15-36. 
which consisted of his parents Juan Diaz de Fuenmayor and Beatriz de Pimentel and four or five siblings. His father the 'licenciado' Don Juan Diaz de Fuenmayor was one of Philip II's counsellors on the Consejo de Castilla. Antonio himself became a canon of the cathedral in Palencia in 1597 and is not known to have left northern Castile prior to his death in $1599 .{ }^{8}$ there may be more documents about the Fuenmayor family in the archives. Yet the dearth of biographical information about Antonio is not really what has dissuaded scholars from engaging with his writing. In fact, we can probably trace their reticence to a specific prejudice within Pius' own nineteenth-century historiography, when Ludwig Pastor and Joseph Mendham dismissed Fuenmayor's Vida as too conventional and essentially derivative of Catena's. ${ }^{9}$ Pastor, like Ranke, excavated Catena's Vita enthusiastically because of its extensive quotations from original sources indeed, to justify this he even reproduced a passage from Catena's preface in which the Italian declares that 'everything I write in these pages is drawn from the original letters of nuncios and princes, and from [Pius'] own instructions and writings'. ${ }^{10}$ Tellingly, in contrast, Pastor does not even credit Fuenmayor as a proper biographer of Pius in a list of such biographers he drew up as an appendix to his text. ${ }^{11}$ But this decision to excise Fuenmayor from Pius' historiography is very unfortunate, not least because the other texts about Pius produced at that time have proved so very interesting to Gotor, Jones, and Rusconi. Fuenmayor's Vida is certainly no less substantial a text than Catena's and, rather than merely plagiarizing, engages in a dialogue with it. That alone might lead us to believe that Fuenmayor merits more scholarly attention. It is surely now opportune to reanimate the Pius he constructed and reflect on his pope's distinctive qualities.

One of the most interesting features of Fuenmayor's text is that its early modern readership rated it extremely highly. It circulated widely and was reprinted at least three times in the early modern period: in $1633,1639,1773.12$ In itself this might seem

${ }^{8}$ Archivo Histórico Provincial de Palencia, Archivo de la Fé Pública, Protocolos notariales: Palencia, legajo 10.204 (old numeration), unfoliated. Javier Gómez de Olea and Pedro Moreno Meyerhoff, 'Los Señores y Marqueses de Fuentehoyuelo', Anales de la Real Academia Matritense De Heráldica y Genealogía, 6 (2000-01), 151-52 (Appendix V); Manuel Vidal, Augustinos de Salamanca: Historia del observantissimo convento de San Augustín (Salamanca: Eugenia Garcia, 1751), 250; Louis Moreri, El gran diccionario historico, o Miscellanea curiosa de la Historia Sagrada (10 vols., Paris: Various Publishers, 1753), Vol. 4, 15. I have also located a family tree in manuscript, Biblioteca Digital Real Academic de la Historia, Referencias: Índice de la Colección Salazar y Castro, 23484, oai:bibliotecadigital.rah.es:49921.

${ }^{9}$ Joseph Mendham, The Life and Pontificate of Saint Pius the Fifth (London: James Duncan, 1832), viii.

${ }^{10}$ Catena, Vita del Gloriosissimo Papa Pio Quinto (Rome, 1587), 3r.

${ }^{11}$ Ludwig Pastor, The History of the Popes from the Close of the Middle Ages, trans. Ralph Francis Kerr (40 vols., London: Kegan Paul, Trench, Trübner \& Co., 1901-53), Vol. 17, 420-6.

12 Antonio de Fuenmayor, Vida y Hechos de Pio V: Segunda Edicion: Añadese el Libro VIII. Que trata de la informaciones hechas para su Canoniçacion y Milagros que ha hecho (Zaragoza: Hospital de Nuestra Señora de Gracia/Pedro Escuer, 1633); Tercera Edicion (Madrid: por la viuda de Juan Sanchez, 1639); Tercera Edicion [sic] (Valencia: Benito Monfort, 1773). On Escuer and the imprint of the Hospital de Nuestra Señora de Gracia, 
to need explaining. However, Fuenmayor's text was not merely popular but also won high acclaim: Fuenmayor's early demise was a great loss for Spanish literature in the judgement of seventeenth and eighteenth-century Spanish writers. Nicolas Antonio (1617-84) wrote as much in his famous Bibliotheca Hispania Nova, published in 1672, stating that the young scholar's classical learning had been deep and his extraordinary skill in Latin withstood comparison with Julius Caesar, Sallust and even Tacitus. ${ }^{13}$ Antonio was not the first to make such claims: Luis Cabrera de Córdoba (1559-1623), famously Philip II's first biographer, had already referred to Fuenmayor as 'the Spanish Sallust and Tacitus', when he cited him in his own text and even the censor officially tasked with approving the 1633 edition of the Vida had supported this comparison adding that not only had the work merited the greatest applause it had received when it was first published but also that the subject matter was so important that it could not be recommended more highly. ${ }^{14}$ The noted Jesuit philosopher Baltasar Gracián (16011658) also praised Fuenmayor's 'vigilante pluma', comparing him to Livy. ${ }^{15}$ Of course, the real sign of success as a writer comes when others parody you - and this happened to Fuenmayor too: the poet Francisco de Quevedo (1580-1645) mocked him in his España defendida y los tiempos de ahora de las calumnias de los noveleros y sediciosos, published in 1609, and lampooned him further in his Premática contra las cotorreras in 1626 when he referenced Fuenmayor's account of Pius' moral crusade against prostitutes in Rome by ironically naming a whore Pio Quinto. ${ }^{16}$ The eighteenth-century satirist Juan Bautista Pablo Fornier (1756-99) was another admirer; Fuenmayor is mentioned in his Exequias de la lengua castillana, where he states that the Spanish language found 'su nervio y vehemencia' in his prose. ${ }^{17}$ In short, Fuenmayor was a man who, in the opinion of other writers of the Siglo d'Oro, might have made a considerable contribution to Spanish literature had he lived longer. The contrast between this judgment about Fuenmayor and that of papal historians raises an obvious question: might there be more to Fuenmayor's text than at first meets the eye? Even if Fuenmayor's work is not of much use for reconstructing the events of Pius' life, its popularity and acclaim surely reveal something important about the development of

see Esperanza Velasco de la Peña, Impresores y libreros en Zaragoza, 1600-1650 (Zaragoza: Institucíon Fernando el Católico, 1998), 104-7. A further edition (Barcelona, 1640), may just be a cataloguing error, Cesáreo Fernández Duro, Tradiciones infundadas (Madrid: Sucesores de Rivadeneyra, 1888), 671.

13 Nicolas Antonio, Bibliotheca Hispana Nova (2 vols., Madrid: Joachim de Ibarra, 1783), Vol. 1, 119.

${ }^{14}$ Luis Cabrera de Córdoba, Felipe Segundo, Rey de España (Madrid, 1619), 693; Juan Alonso de Butron, 'Censura de orden de los Señores del Supremo Consejo', in Antonio de Fuenmayor, Vida y Hechos de Pio V (Zaragoza: Pedro Escuer, 1633), xvii-xviii.

15 Baltasar Gracián, Obras de Lorenzo Gracian (2 vols., Madrid: Pedro Marin, 1773), Vol. 2, 386.

${ }^{16}$ Francisco de Quevedo, 'España defendida y los tiempos de ahora de las calumnias de los noveleros y sediciosos' and 'Premática contra las cotorreras', in Obras en prosa, ed. Felicidad Buendía (4th edition, Madrid: Aguilar, 1958), 87, 514b-15b. See also, Herman Ivantosch, 'Onomastic Invention in the Buscón', Hispanic Review, 29 (1961), 15-32, and 'La vida de Pío Quinto, de Reinoso: une erreur de Quevedo', Bulletin Hispanique, 65 (1963), 322-5.

17 Juan Bautista Pablo Fornier, Exequias de la lengua castillana: sátira menipea, ed. José Jurado, (Madrid: Consejo Superior de Investigaciones Científicas, 2000), 317. 
Pius' cult. Why did such a skilled writer of Spanish take up this subject with such brio and was it just the Vida's literary qualities that impressed later Spaniards?

Several explanations present themselves for the gap between Fuenmayor's place in present historiography and the reception contemporary Spaniards gave his writings. The first is that contemporaries may well have just enjoyed Fuenmayor's work for its literary qualities, as they stated. Fuenmayor obviously aspired that his work be taken seriously as literature, as the lyrical prose style and fair smattering of classical allusions attest. 'The Greeks', 'the Romans', 'the Athenians', 'the Corinthians', 'Cato the Younger', 'Euripides', 'Homer', 'Romulus', 'Hercules', 'the Sybil', 'Ptolemy', 'Solon', 'Scipio', 'Vespasian', 'Theodosius', 'Justinian' all appear in the first two books, though - perhaps importantly - they are absent thereafter. Whether Fuenmayor's text sustains comparison to Tacitus, or any of the other classical authors with whom he was so regularly compared, is harder to say. Fuenmayor may have consciously imitated these earlier historians and he almost certainly had access to their works: Arantxa Domingo Malvadi has documented several examples of his father exchanging manuscripts with the renowned Humanist Juan Páez de Castro. ${ }^{18}$ Yet, Fuenmayor's prose is not as tortured as Tacitus', nor is it as ambiguous in its meaning (Fuenmayor's view of his subject, Pius, is entirely positive). ${ }^{19}$ The modern editor of Fuenmayor's text Llorenç Riber thought that, stylistically, Fuenmayor's prose owed more to Cornelius Nepos than to Tacitus - and it is true that both Fuenmayor and Nepos favour short, clear sentences. ${ }^{20}$ It may be that Fuenmayor did, indeed, engage some structural parallels with Tacitus in the construction of his narrative: for example his description of politics and events in Britain in Book V - a geographical excursus, consideration of the affairs at court, motives and intrigues, accusations and counter-accusations - is vaguely reminiscent of Tacitus' introduction to the Persian war. ${ }^{21}$ Some lesser textual constructions also hint in this direction: for example, a tendency to lead the reader into a story by explaining the general situation first. A good example of this later in Book $\mathrm{V}$ recounts jurisdictional problems in Milan before going on to discuss the difficulty of containing the Protestant threat. ${ }^{22}$ Yet, it is more likely that later Spanish writers' desire to identify Fuenmayor with the great historian simply reflects their on-going efforts to define the form of the historical text. Such debates were often couched in a language of transmission and style which constantly invoked classical authors, as Alberto Alvar Ezquerra and Fabien Montcher have noted. ${ }^{23}$ Beatriz Antón Martínez has shown how

\footnotetext{
18 Arantxa Domingo Malvadi, Bibliofilia Humanista en tiempos de Felipe II: la biblioteca de Juan Páez de Castro (Salamanca: Ediciones Universidad de Salamanca, 2011), 160, 166, 574.

19 On Tactius' ambiguity, see John Henderson, 'Tacitus:/the World in Pieces', Ramus, 18 (1989), 167-210.

20 Riber (ed.), Vida y Hechos de Pío V, vii.

21 Ibid., 186-89.

22 Ibid., 194-95.

${ }^{23}$ Alvar Ezquerra and Montcher, 'Cervantes and the Political Turn of History', 16.
} 
important a point of reference in this Tacitus himself was: a Tacitean movement manifested itself in early seventeenth-century Spain with particular virulence, perhaps in part because of his novelty. ${ }^{24}$ The first Spanish translation of the Annales appeared in 1613, while the first Latin edition published in Spain came only in 1687, so the epithet 'Tacitean' remained a cutting-edge compliment much later than we might otherwise have supposed. ${ }^{25}$

If the literary qualities of Fuenmayor's work are not enough to justify its celebrity in seventeenth-century Spain, then its content surely is. Fuenmayor's Pius is certainly an extremely holy figure who exhibits all the behaviours of a Counter-Reformation saint: humility, austerity, irreproachability and, above all, devotion to the faith. But in this Fuenmayor's Pius is not so different to Catena's. The most important divergence between the two, on a purely hagiographic level, is simply the superior construction of Fuenmayor's text compared to Catena's, which has no organizing principle and consists not of chapters but rather of short sections with verbatim quotations from documents. Arguably, this allows Fuenmayor to develop a richer character for his subject. Moreover, Fuenmayor's primary vehicle for developing Pius is through detailed anecdotal stories which often lead to imagined speeches put directly into Pius' mouth per Thucydides. In an early incident, while still a prior in Alba, Pius fearlessly confronted a troop of three hundred disruptive soldiers whom he had allowed to lodge in his convent. Throwing them out on the street, he exclaimed: ¿Qué es esto? ¿Aun la iglesia y lugares sagrados no han de valernos contra vosotros? ¿Que harán los Alemanes herejes cuando los católicos se atreven a la religion?' 'En defensa de la Iglesia, decir y morir', he added, for good measure. ${ }^{26}$ This story establishes a number of themes which Fuenmayor repeats throughout the two books specifically devoted to Pius' life: his personal courage, his zeal against heretics, and his determination to uphold the dignity of the Church. A later story relates his brave public opposition to Pius IV's decision to promote the young brother of the duke of Mantua and the even younger son of the duke of Florence to the Sacred College. When the Florentine ambassador came to thank the cardinals for their support Pius spoke plainly to his face: 'Señor, erráis; yo os he contradicho, no por querer mal al Duque, sino por juzgar que ni a él ni a la Iglesia convenía'. The other cardinals marveled to themselves, 'entre tantos señores, entre tanta nobleza; ¿solo osa hablar un pobre frailezuelo?' 27 In Book II, in presenting Pius as an ideal pontiff, Fuenmayor dwells notably on his policy of promoting men only on the basis of

${ }^{24}$ Beatriz Antón Martínez, 'La receptio del Tacitismo en España: La "Vía Hispánica”' Bibliothèque d'Humanisme et Renaissance, 53 (1991), 329-345 and El Tacitismo en el siglo XVII en España. El proceso de receptio, (Valladolid: Universidad de Valladolid, 1992); Las obras de Cornelio Tácito traducidas de latin en castellano por Emanvel Sveyro (Antwerp: Pedro Bellero, 1613). See also, Fabien Montcher, 'Du libertinage érudit français au tacitisme ibérique: le commerce du savoir dans les réseaux politiques de la République des Lettres', Alexandra Merle and Alicia Oïffer-Bomsel (eds.), Tacite et le Tacitisme en Europe à l'époque moderne (XVIe-XVIIe siècle), (Paris: Honoré Champion, forthcoming).

25 Saúl Martínez Bermejo, Translating Tacitus: The Reception of Tacitus' Works in the Vernacular Languages of Europe, $16^{\text {th }}-17^{\text {th }}$ Centuries (Pisa: Edizioni Plus, 2010).

${ }^{26}$ Riber (ed.), Vida y Hechos de Pío V, 22-23.

27 Ibid., 41-42. 
character, his personal attributes (including modesty, humility and frugality) and on his many reforms, in particular of morality in Rome and of the curia and the administration of the Papal States.

Fuenmayor's depiction of Pius and the context into which he inserts him at first glance may seem straightforward. But further reflection suggests otherwise. For one thing, such hagiographic figures were never mere literary constructs but were always also living political statements. Pamela Jones has shown how this was the case with Catena's and later Italian depictions of Pius. Indeed, Miguel Gotor and Roberto Rusconi both argue, convincingly, that a powerful impetus for chronicling Pius' life in Italy took shape only after Sixtus V's accession in 1585. The only immediate post mortem attempt to narrate his life, a short text by Tommaso Porcacchi, languished in manuscript form until 1914 (although the sermon Antonio Mureti gave at Pius' funeral did circulate as a pamphlet). ${ }^{28}$ Sixtus encouraged Pius' cult specifically as a propaganda tool to promote his own image by association - not only did he commission Catena to write his biography of Pius but he also translated Pius' remains to a new tomb in Santa Maria Maggiore (opposite the one Sixtus was building for himself) and opened a beatification process for him as the first step on his path to sainthood. Sixtus, who followed a policy of strenuously trying not to over-commit papal support to Philip II of Spain's crusade against Protestants in France and England, seems to have hoped to deflect criticism of his inaction by cultivating the memory of Pius as the pope militant. Pamela Jones sees Pius' military activities as dominant in the image of him in Sistine propaganda, at the expense of all else. In her view, this was what also made it impossible for Sixtus to promote Pius successfully as a saint - one reason that his canonization was delayed another hundred and thirty years. ${ }^{29}$ Fuenmayor's Pius is no less political than Catena's/Sixtus'. Where Catena's Pius was a highly Roman figure, Fuenmayor's is decidedly Spanish; he places heavy emphasis on his concern not just for Italians but for the good of the whole Christian community which is why the protagonists of Pius' efforts are referred to routinely as 'los Católicos'. ${ }^{30}$ Both the construction of Fuenmayor's narrative and individual episodes within it make plain that Spain, not Rome, is the centre of his Christian world. The entirety of Book IV concern events that take place in Spain, with Pius playing only a modest part in the narrative when he comments on the action. Many other episodes also bring Spain to the fore, even where it would appear to have been tangential to the story. Spanish agency permeates the story of Pius' election through the figure of the ambassador Luis de Requesens. Requesens makes a grand speech which sways the cardinals. Specifically, he warns them of the many dangers facing Christendom and pleads with them to choose a pope who has the qualities to overcome them: 'un hombre santo, religioso de Fe probada, enemigo descubierto de herejes, de ánimo levantado y celoso, sin parientes perturbadores, que aspiren a ser tiranos de Italia, $\mathrm{y}$, finalmente un hombre a quien virtud, $\mathrm{y}$ no

\footnotetext{
${ }^{28}$ Porcacchi's 'Vita di Pio V' is reproduced along with two other textual fragements about Pius in François van Ostroy 'Le pape saint Pie V', Analecta Bollandiana, 33 (1914), 187-215; M. Antonii Mureti, Oratio habita in funere Pii V Pnt. Maximi (Rome: apud haeredes Antonii Bladii, 1572), copy in the Archivio di Stato di Mantua, Archivio Gonzaga 1062.

${ }^{29}$ Jones, 'The Pope as Saint', 55.

${ }^{30}$ Riber (ed.), Vida y Hechos de Pío V, 121.
} 
parcialidades, pongan en la silla de San Pedro'. ${ }^{31}$ Just to remove any ambiguity about the Monarquía's seminal role in Pius' success, Book II opens with the enthusiasm with which news of his election was greeted in Spain. ${ }^{32}$

The 'Spanishness' of Fuenmayor's Pius must therefore be an important part of the explanation for his text's appeal. But, even so, it is still insufficient to explain it purely in terms of patriotism. Fuenmayor's text may have been patriotic in a certain sense, but it also raised a specific problem: celebrations of the lives of popes were an inherently problematic genre in late sixteenth-century Spain. Philip II had become increasingly sensitive to any publication which overtly or even implicitly challenged his royal prerogatives as his reign progressed. An account of the life of a man who had fought Philip hard over ecclesiastical jurisdictions was thus necessarily at risk of censorship. ${ }^{33}$ Catena's Vita del gloriosissimo papa Pio Quinto had indeed fallen foul of the censors when it had arrived in Spain in 1586 for this very reason. It had had to be reissued in a new edition in 1587 which expunged, amongst other things, any references to the pope defending papal rights against the Spanish Crown. And yet, as Juan Luis Castellano has argued, in one of the few interventions about the papacy's historiography in early modern Spain, the Spanish crown inevitably faced a dilemma about what to do about such texts because, in the confessionalized world of the late sixteenth century, the Church and, therefore, also the papacy were integral parts of the history of Spain and the Monarchy themselves. ${ }^{34}$ Paolo Broggio has drawn our attention to another text, Gonzalo de Illescas' Historia pontifical, general y católica, published in 1565 in Dueñas, also in the province of Palencia, which gave brief biographies of individual popes and accounts of their times from Christ himself down to Pius V. The Historia pontifical had a chequered history in both Spain and Italy: its original version was too anti-Roman to be acceptable to the Holy Office in Italy and was eventually censored in Spain too. ${ }^{35}$ Illescas' Historia at least fitted into what Broggio terms 'the ideology of a Spanish Catholicism,

\footnotetext{
31 Ibid., 46.

32 Ibid., 72-3.

33 On Inquisitorial censorship under Philip II, see Lucienne Domergue, La censure des livres en Espagne à la fin de l'Ancien Régime (Madrid: Casa de Velázquez, 1996), 15-21, and Henry Kamen, The Spanish Inquisition: A Historical Revision (New Haven: Yale University Press, 1998), 103-36. On Pius' jurisdictional conflicts with Philip, see José Garcia Oro, 'Felipe II: ¿Reforma Española o reforma tridentina?' in Ricardo GarcíaVilloslada (ed.), Historia de la Iglesia en España (5 vols., Madrid: Biblioteca de autores Cristianos, 1979), Vol. 3-1, 323-30; Ignasi Fernández Terricabras, Philippe II et la Contre-Réforme: l'église espagnole à l'heure du Concile de Trente (Paris: Publisud, 2001), 555-85.
}

34 Juan Luis Castellano, 'La monarchia spagnola come paradigma di una monarchia confessionale', Dimensioni e problemi della ricerca storica, 172 (2008), 175-6.

35 Paolo Broggio, 'Una Spagna pontificia. La "Historia pontifical y católica” e la politica culturale della Monarchia spagnola nell'età della Controriforma, in François-Xavier Bischof and Sylvio de Franceschi (eds), Histoires antiromaines II. L'antiromanisme dans l'historiographie ecclésiastique catholique (XVIe-XX siècles). Actes de la journée d'études de Munich (13 septembre 2012), Chrétiens et Sociétés, Documents et mémoires, 23 (Lyon: LARHRA RESEA, 2014), 39-72. Gonzalo de Illescas, Historia pontifical y católica (2 vols. Barcelona: Sebastian de Cormellas, 1622). 
without stain, Spanish before even Roman'. ${ }^{36}$ We might therefore ponder on whether Fuenmayor's text fits into this tradition too and how it seemingly avoided direct censorship. The problem is all the greater because of at least one line in Book V, where Fuenmayor relates a letter Pius wrote to the Venetian Senate in the midst of a dispute: el Pontífice tiene jurisdición temporal sobre todos los Cristianos, y más sobre los que no reconocen superior'. ${ }^{37}$ of course, Fuenmayor was reporting Pius' views rather than advocating them, but even so, it is hard to see why this assertion of papal primacy would have been acceptable in Madrid. It begs a question about context: what conditions were necessary for it to become so?

The immediate context of the Vida y Hechos' composition is still obscure and will probably always remain so. However, we can reconstruct enough about it to offer a plausible set of reasons for why the book came to be both written and published. Certainly, the initial idea of a book seems likely to have involved its dedicatee Francisco de Reynoso, a former steward of Pius within the Apostolic Palace who, since 1572, had languished as the abbot of an undistinguished house at Husillos near Palencia (the abbey was later suppressed in 1606 on account of the depopulation of the settlement). ${ }^{38}$ We cannot prove definitively that Reynoso had ambitions to advance further in the Church than this relatively unrewarding provincial office, but this seems highly probable based on his life story and his own hagiographic record. While working in the Apostolic Palace in the early 1570s, Reynoso had successfully persuaded his master to lobby Philip II to grant him the prestigious and lucrative post of archdeacon of Toledo. ${ }^{39}$ However, Philip had refused to appoint Reynoso because of his status as a converso the rules of the Holy Church of Toledo simply forbade such an appointment, Philip informed the pope. ${ }^{40}$ We might speculate that Reynoso's converso status was precisely why Reynoso's father had sent Francisco and his two brothers to Rome in the 1550s to

36 Broggio, 'Una Spagna pontificia', 71. Katherine van Liere has also written on the agenda to create an authentically Spanish Catholicism at this time, 'Renaissance Chroniclers and the Apostolic Origins of Spanish Christianity', in Katherine van Liere, Simon Ditchfield and Howard Louthan (eds), Sacred History. Uses of the Christian Past in the Renaissance World (Oxford: Oxford University Press, 2012), 121-44.

37 Riber (ed.), Vida y Hechos de Pío V, 194.

38 David Marcos Díez, La Abadía de Santa María de Husillos: estudio y colección documental (904-1608) (Palencia: Diputacíon de Palencia, 2011).

39 The correspondence relating to these negotiations is published in Luciano Serrano, Correspondencia diplomática entre España y la Santa Sede durante l Pontificado de S. Pío V (4 vols., Madrid: Instituto Pio IX, 1914), Vol. 4, 259-60, 284, 354, 481, 493-94.

40 On the problem conversos faced in the Spanish Church, see Helen Rawlings, 'The Secularisation of Castilian Episcopal Office Under the Habsburgs, c. 1516-1700', Journal of Ecclesiastical History, 38 (1987), 61-65, and Albert Sicroff, Les Controverses de status de 'pureté de sang' en Espagne du XVI au XVIII siècles (Paris: Didier, 1960). In fact, Reynoso appears to have had a letter of 'naturalization', which Philip now revoked, see Serrano, Correspondencia diplomática, Vol. 4, 166n. 
try their luck in papal service rather than in the Castilian Church. ${ }^{41}$ There were further elements to his family story which damaged his prospects of an ecclesiastical career in Spain: specifically, a tragedy which occurred in 1559, when the Inquisition condemned one of Reynoso's sisters to death and another to perpetual confinement, in both cases for Lutheran heresies. ${ }^{42}$ Philip had offered Reynoso the Abadia of Husillos and a small pension drawn from the Toledan archdeaconry as compensation for his humiliating rebuff, but by the early 1590s it must have seemed likely that he would receive no further preferment. Now in his mid-sixties, if he was to advance further he had to catch the king's eye or win over someone close to him at court who had influence over the increasingly centralized process of episcopal appointments. What better way for Reynoso to counter any suspicions about his background than through a book which would emphasize his important connection to the pope who had been the Spanish Monarchy's best friend amongst recent pontiffs and who was certainly the most notable for his commitment against heretics and infidels? Reynoso had long been interested in the possibilities of cultural patronage as a means of refashioning his identity and asserting his status. According to Reynoso's own hagiographer, the Benedictine Gregorio de Alfaro, his main consolation in his years at Husillos had been buying up 'muy buenas tapicerias, mucha plata, y otras cosas de mucho precio, como lo suelen hazer los principes ricos y moços, sin mucha experiencia'. ${ }^{43} \mathrm{He}$ was a great lover of all the arts, importing a number of paintings by Titian and other Italians, and his chamber apparently never lacked for the sound of music. He may also have had a hand in the decision by the cathedral chapter in Palencia to commission El Greco's San Sebastián, though this is impossible to prove. ${ }^{44}$

Under different circumstances Reynoso's self-fashioning may or may not have succeeded in achieving his objectives and advancing his career. However, several factors, even beyond the lack of censorship, suggest that the decision to publish Fuenmayor's text may have owed as much to support from the Spanish crown as it did to Reynoso's own efforts. The first factor is the circumstances in which Fuenmayor's final text appeared. The date 1595 - twenty-three years after Reynoso's return to Spain - must be significant: this was the year that Clement VIII was reconciled with the French king Henry IV, readmitting him into the Catholic faith and, in the process, frustrating more than a decade of Spanish foreign policy. ${ }^{45}$ Was the decision to publish

${ }^{41}$ Gregorio de Alfaro, Vida del Illustrissimo S[eñ]or D. Francisco De Reynosso, obispo de Cordoba (Valladolid: Francisco Fernandez de Córdoba, 1617), 4v-5r.

42 Jesús Alonso Burgos, El luteranismo en Castilla durante el siglo XVI: autos de fe de Valladolid de 21 de mayo y de 8 de octubre de 1559 (San Lorenzo de El Escorial: Swan Avantos \& Hakeldama, 1983), 62-63, 84; Manuel de Léon de la Vega, Los protestantes y la espiritualidad evangélica en la España del Siglo XVI (2 vols., Oviedo: Consejo Evangélico del Principado de Asturias, 2011), Vol. 2, 320-1.

${ }^{43}$ Alfaro, Vida del Illustrissimo S[eñ]or D. Francisco De Reynosso, 24r-v (this folio is incorrectly numbered '16' in the copy I consulted).

44 On Reynoso's role as a patron in Palencia and the context of his patronage there, see Antonio Cabeza Rodríguez, 'Palencia en la Roma española', Publicaciones de la Institución Tello Téllez de Meneses, 80 (2009), 45-106, esp. 87-93.

45 On Henry's reconciliation with Clement, see Alain Tallon, 'Henri IV and the Papacy after the League', in Alison Forrestal and Eric Nelson (eds.), Politics and Religion in Early 
Fuenmayor's Vida part of a less than subtle attempt to criticize the reigning pope through the example of one of his predecessors? Fuenmayor's own father's connection to Philip is suggestive (whether or not his father was still alive at this time is unclear.) Moreover, Trevor Dadson has shown that the printer of Fuenmayor's Vida, Luis Sanchez, who had first set up shop in Madrid around 1591, had already become identified with the court by the date of publication - and, indeed, he acquired the title 'impresor del Rey' not long after. ${ }^{46}$ Fuenmayor's preface itself hints that the timing of publication was not entirely of his own choosing: he states that he has been working on the manuscript for more than a year, but is not yet happy with its state. 'Son trabajos de mocedad y de pocos días', a phrase which might be mere rhetorical modesty but, equally, could express Fuenmayor's disquiet at being forced to surrender his manuscript to others too quickly. ${ }^{47}$ Thomas Dandelet has written of Philip II's wider efforts to claim Catholicism as an agent of Spanish imperialism, for example through his earlier commission of the 'Allegory of Lepanto and Philip II' from Titian and Titian's reciprocal gift to him of 'Spain coming to the aid of Religion', so it is entirely plausible that Philip would have grasped the potential of a life of Pius as propoganda. ${ }^{48}$ Moreover, a royal hand ushering the Vida $y$ Hechos into print in haste would explain why the text's literary markers curiously disappear after Book II. Of course, royal approval would also account for Fuenmayor's success in attracting literary attention and for why the censors overlooked its en passant defence of the pope's temporal primacy. Again, the evidence is not definitive, but it is suggestive. There is plenty in Kagan and Alvar Ezquerra and Montcher to support such a theory that Philip patronized Fuenmayor not of out a desire to see Pius canonized per se but rather to marshal his memory in support of Spain's interests.

If the theory of royal involvement in the production of Fuenmayor's text is true then the key question, of course, becomes how does it work as a criticism of Clement VIII? In stylistic terms, the use of a past pope to condemn the current one was extremely Tacitean, as all the seventeenth-century Spanish authors perhaps recognized. Moreover, the critical readings soon reveal themselves once Fuenmayor's Pius is set explicitly against Clement. In 1595 Clement was notable for two things: one was his nepotism, the other was his heavy investment in his self-image, in particular the emphasis he placed on himself as a peacemaker and a paterfamilias or padre comune, equidistant to the two great Catholic powers of France and Spain whose principal political role was to act as a

Bourbon France (Basingstoke: Palgrave Macmillan, 2009), 21-41, and Maria Teresa Fattori, Clemente VIII e il sacro collegio: Meccanismi istituzionali et accentramento di governo (Stuttgart: Hiersemann, 2004), 20-82.

46 Trevor Dadson, Libros, Lectores y Lecturas: Estudios sobre bibliotecas particulares españolas del Siglo de Oro (Madrid: Arco/Libros, 1998), 309n. See also, Maria Montáñez Matilla, 'Un impresor madrileño del siglo XVII: Luis Sánchez', Revista de la Biblioteca, Archivo y Museo del Ayuntamiento de Madrid, 20, No. 61-62 (1951), 313-8.

47 Riber (ed.), Vida y Hechos de Pío V, 10.

48 Thomas Dandelet, Spanish Rome, 1500-1700 (New Haven: Yale University Press, 2001), 65-83, esp. 71-73; Geoffrey Parker, Imprudent King: A New Life of Philip II (New Haven: Yale University Press, 2015), 92-9. We might also note Dandelet's recent cynicism about Philip's embrace of imperial Catholicism, The Renaissance of Empire in Early Modern Europe (Cambridge: Cambridge University Press, 2014), 139, 146, 188-9. 
broker between them. ${ }^{49}$ It is easy to read much of what Fuenmayor's Pius says as an attack on one or other of these attributes: his fierce criticisms of nepotism and of making curial appointments on any basis other than good character indirectly condemns the former. When those present question Pius' reform of the Roman curia, Fuenmayor has the pope justify what he did in the following terms: 'Menos daño es que destruir la Cristiandad'? ${ }^{50}$ The apposition between the interests of the curia and of Christendom cannot be other than deliberate. Elsewhere Fuenmayor's text expresses frequent anti-French sentiment which reminds the reader of the foolishness of Clement's rehabilitation of Henry. Book V criticizes Charles IX, whose unreasonable actions prevented the marriage of his sister to the Portuguese king Sebastian - an intervention which had fateful consequences for both kingdoms. ${ }^{51}$ In fact, Book IV, which is mostly about Spain, contains the most blatant attack on Clement's pro-French sympathies. Here, Fuenmayor relates at some length Pius' concern on learning of the discovery of chests full of copies of Calvin's Catechism in Lyons and Toulouse, translated into Spanish and apparently ready for import into Iberia. Fuenmayor contrasts Pius' sadness at the failure of the French monarchy to protect the true Catholic faith with his hopeful exhortation of Philip to guard against the intrusion of such heresies into Spain and to enact legislation to prevent any books entering his dominions except those approved by the commissaries of the Holy Office. ${ }^{52}$ In fact, the entire second half of Fuenmayor's text is filled with pro-Habsburg propaganda which, above all, emphasizes Pius' special affection for Philip. Where Catena's Pius was tetchy at best about the Catholic King, Fuenmayor voices Pius' 'ternisimo' love for him - the pope recognized that he and the king shared the same religious zeal In Fuenmayor's account Pius raised his hands to the heavens when the Spanish ambassador in Rome informed him that Philip has fallen ill and pleaded with God to spare the king's life and shorten his own days instead..$^{53}$ In the opening section of Book V Fuenmayor reminds the reader again that the House of Austria was 'devotissima siempre de la Romana Yglesia'. ${ }^{4}$

Unsurprisingly, in so far as we can construct their contexts, later editions of Fuenmayor's text, seem to have been equally the progeny of political circumstances, though the dramatis personae involved were somewhat different. In an ironic twist, which reversed the positions of king and pope under Sixtus V, the Spanish crown now supported Pius' canonization while the pope, Urban VIII, opposed it. As Simon Ditchfield has shown, Urban preferred to champion the cause of Gregory X, whom Urban believed

\footnotetext{
${ }^{49}$ Agostino Borromeo, 'Clément VIII, la diplomatie pontificale et la paix de Vervins', in Jean-François Labourdette, Jean-Pierre Poussou and Marie-Catherine Vignal (eds.), Le Traité de Vervins (Paris: Presses de l'Université de Paris-Sorbonne, 2000), 323-44; Christian Schneider, 'Types of Peacemakers: Exploring the Authority and SelfPerception of the Early Modern Papacy', in Stephen Cummins and Laura Kounine (eds.), Cultures of Conflict Resolution in Early Modern Europe (Farnham: Ashgate, 2016), 90-3, and Pope Clement VIII and Confessional Conflict: International Papal Politics and Diplomacy (1598-1605), PhD Diss., Durham University (2016).

50 Riber (ed.), Vida y Hechos de Pío V, 73.

51 Ibid., 202-03.

52 Ibid., 172.

53 Ibid., 170.

54 Ibid., 175.
} 
to provide a more pacific model for the papal saint. ${ }^{55}$ Both seventeenth-century reissues of Fuenmayor formed part of the Spanish crown's response to Urban VIII's decision to derail Pius' canonization process, which was ostensibly taken on the grounds of a lack of proven miracles. The 1633 text, which was dedicated to the up-andcoming cleric Juan Palafox y Mendoza (1600-59), chaplain to Maria Anna of Spain, queen of Hungary and Bohemia, was published with an additional seventh book, printed after the six books of Fuenmayor's original, which laid out at great length a series of miracles attributed to Pius and explicitly stated that a Dominican friar had noted them down from the document of the original canonization process. ${ }^{56}$ The challenge to Urban's position was implicit but, equally, impossible to miss. All these factors might seem to justify the suspicion of partisanship with which Pastor approached Fuenmayor's work, except for one thing: they merely parallel the origins of Catena's Vita del gloriosissimo papa Pio Quinto. Pastor was clearly aware that the reason Catena had access to such an extensive documentary base was because Sixtus V had explicitly commissioned him to write the work and most editions of Catena include the text of Sixtus' privilege granting him access. Surprisingly, nevertheless, Pastor's chief criticism of Catena is rooted less on perception of bias than of perception of dullness: 'Catena's biography is rather a collection of facts, which, however, is of considerable value to-day on account of its full character. This explains why it has served as the basis for all the later biographies of the Pope'. ${ }^{57}$ The same considerations are, of course, also true of Gabuzio's Latin Vita from 1605. This version of Pius' life, it is worth pointing out, eventually found its way into the Acta Sanctorum in 1680 and thus, in effect, became the official vita. Miguel Gotor has reconstructed the negotiations that took place under the patronage of Pius' protégé Antonio Carafa (1538-91) and his cardinal nephew Michele Bonelli (1541-98) about transforming Catena's Life into Gabuzio's - negotiations which took place in the face of protests from Catena, threats to bring the matter to the attention of the Holy Office, and concern at the possible Spanish reaction. ${ }^{58}$

\section{IV}

Two things follow from this discussion: first, teasing out the political agenda within a hagiographic document is sometimes revealing in and of itself, and, second, that the relative importance attached to different hagiographic texts about the same saint may be as much a function of later historiography as it is of their intrinsic merit as texts. These conclusions are already well embedded in the historiography of CounterReformation constructs of sanctity, although it is nevertheless worth repeating them. The various early modern 'Lives of Pius V' underline just how complex a business saintmaking could be by the end of the sixteenth century: a process which involved constantly shifting coalitions, the members of which might have quite different motives

\footnotetext{
55 Simon Ditchfield, 'How not to become a Counter-Reformation Saint: The Attempted Canonization of Pope Gregory X, 1622-45', Papers of the British School at Rome, 60 (1992), 402.

56 Antonio de Fuenmayor, Vida y Hechos de Pio V (Zaragoza: Pedro Escuer, 1633), 197r, 218r-v.

57 Pastor, History of the Popes, Vol. 17, 421.

58 Gotor, 'Le vite di San Pio V', 236-40.
} 
for promoting the candidacy or want to use it to promote quite different exemplary models. This was surely especially true for popes put forward for canonization: not only did all recent pontiffs come with plenty of detractors as well as supporters, but any case on a former pope's behalf in itself necessarily proposed an ideal for the figure of the pope: what qualities he should embody, what policies he should pursue, how others should react to him. Saints from other backgrounds might similarly influence perceptions of the role they had occupied during their lifetime, but in a less absolute way. Catholics could simultaneously accept multiple interpretations of the figure of beata, the bishop, or the holy hermit, but they could only really hold one model for the occupant of the papal office. This was surely even more emphatically true after Trent, when popes themselves began to invest in a cult of personality based around constructs not of princely power but of personal sanctity. The individual papal vitae produced in the Council's aftermath reflected that, whatever their specific political overtones.

My reconstruction of the context of Fuenmayor's Vida y Hechos de Pío V also highlights a further complicating factor: the historiography of Spanish saint-making. Several scholars, notably Thomas Dandelet and Clare Copeland, have documented the Spanish crown's seemingly wide programme for promoting favoured cults, especially those of its Iberian subjects. ${ }^{59}$ Of the thirty-two new saints proclaimed in the seventeenth century, thirteen were Spanish, two Portuguese, one from Peru and only nine from Italy. 60 Copeland has rightly pointed out that not all these Hispanic saints were supported by the crown and, even amongst those who were, the crown's support was not necessarily a decisive factor. Yet, the example of Pius' case, first vigorously opposed and later promoted by the Spanish Monarchy, demonstrates the danger of seeing Italians and Iberians in two contrasting blocks and lays bare the fluidity of identities at this time. Fuenmayor himself constitutes an interesting figure in the context of historiography, as it developed as a genre at the Spanish court. Alvar Ezquerra and Montcher divided royal historiographers into two categories: those engaged in the writing of Spain's general history and those akin to political counsellors. Fuenmayor fits neither category and is also a significant outlier from the ideal they identify: a man of forty years with experience of life and travel. ${ }^{61} \mathrm{He}$ and, indeed, the Gonzalo de Illescas suggest the existence at this time of a rather broader programme of royal historiography and historiographers. However, it does affirm Richard Kagan's contention that such historiographers were no mere artisans of glory (to paraphrase Orest Ranum's earlier

59 Thomas Dandelet, 'Celestial Heroes and the Splendor of Iberia: Spanish Saint Making in Early Modern Rome', in Helen Hills and Giovanna Fiume (eds.), Il santo patron e la città: San Benedetto il Moro: culti, devozioni, strategie di età moderna (Venice: Marsilio, 2000), 183-98; Clare Copeland, 'Spanish Sains in Counter-Reformation Italy', in Piers Baker-Bates and Miles Pattenden (eds.), The Spanish Presence in Sixteenth-Century Italy: Images of Iberia (Farnham: Ashgate, 2015), 103-26.

60 On these canonizations, see Christian Renoux, 'Canonizzazione e santità femminile in età moderna', in Luigi Fiorani and Adriano Prosperi (eds.), Storia d'Italia, Annali 16. Roma, la città del papa: vita civile e religiosa dal giubileo di Bonifacio VIII al giubileo di papa Wojtyła (Turin: Einaudi, 2000), 731-51.

${ }^{61}$ Alvar Ezquerra and Montcher, 'Cervantes and the Political Turn of History', 24n. 
study of the historiographers of France). ${ }^{62}$ Like those Kagan studies, Fuenmayor and his patron Reynoso were guided by their personal ambitions and networks, which makes incorporating their productions into a straightforward narrative of royal history more difficult. Moreover, as Broggio and others have shown, the anti-papal subtext of the Vida $y$ Hechos de Pío $V$ is hardly out of keeping with other Spanish literary production of this period, even if the strength of declaration in favour of Pius $V$ perhaps was. By focusing on an individual pontiff and his actions, Fuenmayor's text addressed the Spanish Monarchy's need to incorporate the papacy into its writing of history in a manner that differed from the Historia Pontifical - one that was more flexible precisely because it channeled its anti-Roman agenda through a single individual. Yet, unlike the popes in the Historia Pontifical, Fuenmayor's Pius V was simultaneously a generic example of all a pope should be and a specific historical individual who could be contrasted with the papal office's current incumbent.

In the event, Fuenmayor's Vida y Hechos de Pío $V$ does not seem to have proved a particularly effective weapon for attacking Clement VIII and it did little to help Philip reassert the Spanish Monarchy's dominance over papal politics. As Maria Teresa Fattori has shown, Clement VIII was just too dominant at this point in his reign for a mere literary endeavour to impact meaningfully on the momentum he was building for his chosen policies. ${ }^{63}$ Philip, meanwhile, had entered the winter of his life. Geoffrey Parker and José Ignacio Tellechea Idígoras have reconstructed his decline from late 1594, in the latter case as chronicled in the reports of papal nuncios: becoming progressively more frail, possibly as a result of cancer, until he succumbed to an agonizing final illness which at one point saw him covered in boils and sores. ${ }^{64}$ Philip's agents in Italy sensed that this was the end of an era - Michael Levin has argued that they had already adopted a new priority, namely to disentangle the monarchy as much as possible from anything which might further endanger its hegemony (such as renewed military conflict). ${ }^{65}$ The limited purchase that Fuenmayor's Vida brought Philip and his successor Philip III is perhaps to be expected under those circumstances. However, it is worth pointing out the more positive effect it may have had on Francisco de Reynoso's career: in 1597, at the age of sixty-three, Philip appointed him to the bishopric of Córdoba, one of the richest and most important sees in metropolitan Spain. There is, however, no evidence that Fuenmayor himself reaped any reward for writing the Vida in the four remaining years of his short life. The posthumously extended 1633 edition of his text, which attacked Urban VIII, might be viewed as having been marginally more successful in furthering Spanish interests. In spite of Urban's best efforts, the campaign to canonize Pius continued throughout the 1630s (hence the publication of the third edition of Fuenmayor in 1639). In 1640 a further new Life of Pius by François Goubau appeared at

62 Orest Ranum, Artisans of Glory: Writers and Historical Thought in Seventeenth-Century France (Chapel Hill: University of North Carolina Press, 1980).

${ }^{63}$ Maria Teresa Fattori, 'Clemente VIII e il suo tempo negli studi storici (1592-1605)', Cristianesimo nella storia, 22 (2001), 23-64, and Clemente VIII e il sacro collegio, 301-60. 64 José Ignacio Tellechea Idígoras, El ocaso de un rey: Felipe II visto desde la nunciatura de Madrid, 1594-1598 (Madrid, 2001). On Philip's death, see also Parker, Imprudent King, 353-56.

65 Michael Levin, Agents of Empire: Spanish Ambassadors in Sixteenth-Century Italy (Ithaca: Cornell University Press, 2005), 129-30. 
Antwerp, this time dedicated to the Cardinal-Infante Ferdinand of Austria. Urban died in 1644 and thereafter activity in support of Pius gathered pace: Catena's Life was reissued in Rome in 1647 and Agazio di Somma wrote another Vita di Pio $V$ in manuscript form, which Miguel Gotor has shown to have been essentially a development of Porcacchi's brief early text. Crucially, di Somma's Vita was published in Paris in French translation, certainly in 1672 and possibly also in an earlier edition in 1650 - a development which intimates that Pius was no longer an uncontested 'Spanish' saint but one with supporters amongst Spain's traditional enemies. ${ }^{66}$

Pius' legend speaks to the constantly evolving nature of the papal identity throughout the early modern period and throughout the Tridentine Church. Clement X beatified Pius in 1672 and Clement XI finally canonized him on 22 ${ }^{\text {nd }}$ May $1712 .{ }^{67}$ Both these occasions stimulated a renewed interest in Pius as a hagiographic subject: in the former, through new vitae by Ambrosius Randing and an anonymous cleric who dedicated his text to the pope's sister, and through the inclusion of Gabuzio's Life in the Acta Sanctorum, in the latter, through a further republication of Catena's Life and the composition of new ones by Tommaso Minorelli and Paolo Alessandro Maffei. ${ }^{68}$ Pamela Jones has studied how Maffei's Vita relates to Catena's original, noting how it reimagines Pius in line with Clement XI's own ideals for the papal office. No longer is Pius seen as a warrior for Christendom but instead as a papal pastor in the mode later developed more fully by Benedict XIV. ${ }^{69}$ It is also worth noting that, unlike Catena or Fuenmayor, all these late seventeenth-century and early eighteenth-century vitae expressly reference Pius' status as a Dominican in their titles - partly a function of the order's support for his canonization, but also surely part of that process of re-imagining Pius' image in its new, more pastoral form. Pastor identified at least twelve further

${ }^{66}$ Agazio di Somma, La vie du pape Pie V, trans. André Félibien (Paris: Jean Baptiste Coignard, 1672). Eduard Maria Oettinger refers to a 1650 edition in his Historisches Archiv, enthaltend ein Systematisch-Chronologisch Geordnetes Verzeichniss 1700 der Brauchbarsten Quellen zum Studium der Staats- Kirchen- und Rechsgeschichte aller Zeiten una Nationen (Karlsruhe: Christian Theodor Groos, 1841), 43. The original manuscript version is in the Biblioteca Apostolica Vaticana, Chigiani, I.III.69.

67 Clement X, 'Unigenitus Dei Filius', 27 April 1672, and Clement XI, 'Inter mulitiplices', 21 May 1712, in Luigi Tomassetti et al. (eds.), Bullarum, Diplomatum et Privilegiorum Sanctorum Romanorum Pontificum Taurinensis editio (24 vols., Turin: Vecco et Sociis, 1857-72), Vol. 18, 302-4 and Vol. 21, 506-517.

68 Ambrosius Randing, Beatus Pius V. Pontifex Maximus ex Ordine Praedicatorum (Augsburg: Simon Uzschneider, 1672); Tommaso Minorelli, De S. Pio V pontifice maximo ex ordine prædicatorum oratio habita Romæ in Templo S. Mariæ super Minervam vij Idus Augusti (Rome: Francesco Gonzaga, 1712); Paolo Alessandro Maffei, Vita di S. Pio Quinto, Summo Pontifice, dell'Ordine de'Predicatori (Venice: Giacomo Tommasini, 1712).

${ }^{69}$ Jones, 'The pope as saint', 59-68. On Benedict XIV's image as pope, see Mario Rosa, 'Tra Muratori, il giansenismo e i 'lumi': profilo di Benedetto XIV' in Riformatori e ribelli nel '700 religioso italiano (Bari: Dedalo, 1969), 49-85; Roberto Rusconi, 'Benedict XIV and the Holiness of the Popes in the First Half of the Eighteenth Century', trans. Daniel Bornstein, in Rebecca Messbarger, Christopher Johns and Philip Gavitt (eds.), Benedict XIV and the Enlightenment: Art, Science, and Spirituality (Toronto: University of Toronto Press, 2016), 277-96. 
'Lives of Pius' written in the eighteenth and nineteenth centuries up to, but not including, his own contribution in the History of the Popes. ${ }^{70}$ This record almost certainly makes Pius the pope with the single greatest number of biographies and the story of his unfolding post-mortem image amongst the most interesting of any early modern pontiff, with the possible exception of Paul IV (which Alberto Aubert has studied at length). ${ }^{71}$ But because Pius is the only early modern pope actually to have been canonized, he surely remains the most interesting example through which to trace the process of evolving papal identity within early modern Catholicity, and across, Catholic Europe. On one level, his success and the failure of other popes speaks to Pius' versatility, which could be harnessed to further the interests of a variety of actors, and also to the difficulty of reaching consensus about what the role of the pope within Tridentine Catholicism should be: each papal candidate for canonization represented a different ideal for the papal identity and not all of them were sufficiently attractive to enough people to win sainthood. Fuenmayor's depiction of Pius V is an important element within Pius' story: for its intrinsic literary qualities, for what it reveals about the evolving priorities of biography at this time, and for the political uses to which it was put as an apparently authentic text.

70 Pastor, History of the Popes, Vol. 17, 425-6.

${ }^{71}$ Alberto Aubert, Paolo IV: Politica, inquisizione e storiografia (2 ${ }^{\text {nd }}$ edition, Florence: Le Lettere, 1999). 